Article

\title{
An Ecology for Cities: A Transformational Nexus of Design and Ecology to Advance Climate Change Resilience and Urban Sustainability
}

\section{Daniel L. Childers ${ }^{1, \dagger, *}$, Mary L. Cadenasso ${ }^{2, \dagger}$, J. Morgan Grove ${ }^{3, \dagger}$, Victoria Marshall ${ }^{4, \dagger}$, Brian McGrath ${ }^{4, \dagger}$ and Steward T. A. Pickett ${ }^{5, \dagger}$}

1 School of Sustainability, Arizona State University, Tempe, AZ 85287, USA

2 Department of Plant Sciences, University of California, Davis, CA 95616, USA; E-Mail: mlcadenasso@ucdavis.edu

3 U.S. Forest Service, Baltimore, MD 21201, USA; E-Mail: jmgrove@gmail.com

4 Parsons The New School for Design, New York, NY 10011, USA;

E-Mails: marshalv@newschool.edu (V.M.); mcgrath@newschool.edu (B.M.)

5 Cary Institute of Ecosystem Studies, Millbrook, NY 12545, USA;

E-Mail: picketts@caryinstitute.org

$\dagger$ These authors contributed equally to this work.

* Author to whom correspondence should be addressed; E-Mail: dan.childers@asu.edu; Tel.: +1-480-965-2320; Fax: +1-480-965-8087.

Academic Editor: Marc A. Rosen

Received: 18 December 2014 / Accepted: 23 March 2015 / Published: 31 March 2015

\begin{abstract}
Cities around the world are facing an ever-increasing variety of challenges that seem to make more sustainable urban futures elusive. Many of these challenges are being driven by, and exacerbated by, increases in urban populations and climate change. Novel solutions are needed today if our cities are to have any hope of more sustainable and resilient futures. Because most of the environmental impacts of any project are manifest at the point of design, we posit that this is where a real difference in urban development can be made. To this end, we present a transformative model that merges urban design and ecology into an inclusive, creative, knowledge-to-action process. This design-ecology nexus - an ecology for cities - will redefine both the process and its products. In this paper we: (1) summarize the relationships among design, infrastructure, and urban development, emphasizing the importance of joining the three to achieve urban climate resilience and enhance sustainability; (2) discuss how urban ecology can move from an ecology of cities
\end{abstract}


to an ecology for cities based on a knowledge-to-action agenda; (3) detail our model for a transformational urban design-ecology nexus, and; (4) demonstrate the efficacy of our model with several case studies.

Keywords: urban design; urban ecology; design-ecology nexus; urban sustainability; ecology for cities; climate change; climate adaptation; urban resilience

\section{Introduction}

Sustainability is a broad ideal. It links social, environmental, and economic integrity through a process of democratic, inclusive goal setting [1,2]. Further, sustainability is a process, not an outcome or endpoint [3] and the transitions that cities undergo as they move towards more sustainable futures can take many forms [4]. In this paper we propose that an important way to enhance both urban sustainability and climate change resilience is for mutual learning between urban design practice and ecological science, with particular attention to adaptive processes and pluralistic governance. We define "design" as far more than a plan or drawing of an object or space before it is built or made. We conceive design to be the purpose, planning, or intention that exists, or is thought to exist, behind any action or object. It is a conscious effort to create order in all human activity and it includes our perceptions, actions, and review of the impacts of those actions (sensu [5]). Design can play a substantial role in environmental outcomes. For instance, Thackara [6] estimated that $80 \%$ of the environmental impact of any object, including the built environment, is determined at the design stage. Understanding and mitigating that impact demands a process of public deliberation that better integrates design and ecology in order to achieve sustainable urban development.

Throughout the paper, we focus our discussion and examples on challenges that cities face, and will face in the future, associated with climate change-with special emphasis on heat extremes, droughts, and floods. In the case of heat extremes, the urban heat island effect is one of the most well-established features of contemporary urbanization, but its social significance and implications for human health, environmental justice, and urban infrastructure remain important frontiers [7]. In the case of drought and flooding, climate change projections include an increased frequency of extreme precipitation events interspersed by longer, more extreme drought events [8]. Drought is not only a concern of arid-climate cities $[9,10]$. In fact, the effects of drought as a limit to development and as a periodic threat to the functioning of mesic urban systems are becoming more prevalent [10]. However, drought in its various manifestations is often seen as a temporary pulse to be waited out, rather than as a stimulus for sustainable design, adaptation, and planning [11]. On the other hand, stormwater management is a strong stimulus for sustainable design, adaptation, and planning in all cities $[12,13]$. Flood risk is a similar stimulus for river cities, as is the inevitable risk of sea level rise and ocean flooding in coastal cities. All are examples of extreme conditions that are expected to intensify in the future. They often have disproportionate impacts on the most vulnerable populations, such as youth and the elderly, low-income people, people of color, and immigrants [14].

Urban design has been defined by and associated with architects, landscape architects, and planning professionals since the mid-20th century. However, as cities worldwide must adapt to economic 
restructuring, mass migrations, and climate change, urban design is quickly evolving to include civil society, community actors, engineers, and city managers $[15,16]$. The urban design process, as it is more broadly conceived, has the capacity to incorporate and give physical form to our growing scientific understanding of urban regions as social-ecological systems [17] facing new climate change risks and vulnerabilities. Pre-industrial cities were largely designed to provide human comfort in sometimes-hostile conditions. Later, modern infrastructure put distance between urban design and direct climate response, but recent innovations in climate-appropriate architecture and design are beginning to address this dichotomy. We argue that an integrated design-ecology nexus has the potential to stimulate a new era of sustainable urban development based in novel systems of deliberative decision-making and governance. The rationale for this integration was well articulated by Tanner et al. [16], and here we both expand on that rationale and present a model to make it happen. This merging of design and ecology will advance urban sustainability most quickly when a nexus of feedbacks between them is purposefully created to promote adaptive change and risk mitigation in both urban neighborhoods and regions. As our species continues to become more urban [18], this transformational design-ecology nexus is increasingly critical. It will help existing and new cities meet the challenges of growing in sustainable ways while becoming more resilient to severe, climate-induced events. In essence, society cannot adequately meet these challenges if urban design and ecology continue to be practiced as separate fields and in isolation from residents, city governance, and decision-making.

In this paper we: (1) summarize the relationships among design, infrastructure, and urban development with particular emphasis on the importance of joining the three to achieve urban climate resilience and enhance sustainability; (2) discuss the need for urban ecology to move from an ecology of cities $[19,20]$ to an ecology for cities based on a knowledge-to-action agenda; (3) present a model for a transformational urban design-ecology nexus, and; (4) demonstrate the efficacy of our model with several case studies.

\section{Design, Infrastructure, and Sustainable Urban Development}

Urban design became a professional practice in the middle of the 20th century as cities around the world faced the enormous challenges of reconstruction after World War II [21]. Through its development, the large-scale tabula rasa or "blank slate" approach to modern urban planning was replaced by code-based district or patch-scale urban design. This shift emphasized reconstructing or reconnecting to traditional cities and their fine-scale streets, blocks, and open space rather than the large-scale infrastructural emphasis of modern city planning. The discipline of landscape ecology helped shape regional planning approaches to, for example, greenfield development [22,23] and more recent movements labeled landscape or ecological urbanism have focused on post-industrial brownfield redevelopment [24,25]. However a more comprehensive and integrative design-ecology nexus is needed to consider greenfield, brownfield, and greyfield areas of cities while operating at scales of existing and new neighborhood development [26].

It is well known that urbanization is increasing globally, and converting ever-greater areas of land worldwide. In addition to direct land conversion, urban processes, lifestyles, and investments are transforming existing cities while also influencing lands far distant from traditionally recognized cities $[27,28]$. Thus, an urban perspective on and concern for sustainability is increasingly relevant to a 
large proportion of the Earth's land covers, ecosystems, and populations. Many cities are already addressing the need to advance urban sustainability with formal sustainability plans. However, these plans often focus on particular sectors, infrastructure types, or processes, such as transportation, water, or energy [29]. In many cases these sustainability plans are not adequate to prepare cities for the crises and tipping points that so many cities and new urban areas face currently or will experience in the future $[3,4]$. These plans often suffer from a lack of integration and holistic vision that connects across sectors and allows a networked approach to planning for the future. Many sustainability plans also tend to have a narrow focus on existing "hard" infrastructures (e.g., transportation, water supply, and sanitary and stormwater treatment systems) and on "low hanging fruit" green infrastructures (e.g., parks and public trees [30-32]). Furthermore, these plans have rarely been integrated into the smaller-scale neighborhood approach of contemporary urban design practice $[33,34]$.

Urban infrastructure takes many forms. Engineered infrastructure, or "gray" infrastructure, is the capital investments that move or house people, goods, water, waste, and energy and the associated guidelines for their construction, operation, maintenance, and rehabilitation. In most contemporary cities, what is in place today was largely deployed over the past century during the era of the "Sanitary City" [34], when less was known about the environmental, social, and climate change impacts of the physical design of systems. Gray infrastructure was built to protect against environmental hazards by, in general, overdesigning or designing to control the environmental factors [35]. This reduced the likelihood that infrastructure would fail-a "fail safe" goal. This kind of engineered resilience is rigid and unyielding; it is not adaptive and imparts large inertias on urban systems [3]. New approaches that couple infrastructure and urban ecological services are needed, as evidence accumulates that these twentieth century infrastructure design principles often make urban systems more vulnerable to extreme climate events [16,36,37].

Urban infrastructure that incorporates natural elements is often called "green" infrastructure. This includes traditional examples, such a parks and street trees, but also includes more novel urban components such as community gardens and multi-purpose and multi-function stormwater management facilities. Virtually all cities are also characterized by a variety of water features that provide a range of ecosystem services, including rivers and streams, lakes, and fountains. Collectively these are known as "blue" infrastructure. Because green and blue infrastructure features take advantage of natural structures and ecological processes, they are surprisingly adaptable to a changing future, and thus impart resilience to urban systems far more than do inertia-bound gray infrastructures. In fact, there are numerous options for using green and/or blue infrastructure designs instead of gray infrastructure [38]. We argue, as did Tanner et al. [16], that the best strategy for moving in this direction is for the urban design process to expand beyond the realm of engineers and planners in order to include urban ecologists, landscape architects, and deliberative decision-making and governance. Representatives of all disciplines and perspectives should be a part of the design process from beginning to end [39].

Urban design has social impacts across a range of social-ecological scales and can contribute to integrating the ecological functioning of green and blue infrastructure with the finer scales of individuals, urban neighborhoods, and communities. At the level of individuals, environmental stewardship can promote relaxation, mitigate stress, create self-confidence, and strengthen self-sufficiency. At the collective level of neighborhoods and communities, environmental stewardship can help establish trust, strengthen social cohesion, and enhance knowledge sharing [40-42]. Investments in urban 
design, in concert with green, blue, and turquoise infrastructure (Text Box 1), have economic impacts in the real estate sector and the workforce. For example, numerous studies have demonstrated the positive impacts of proximity to parks, community gardens, and tree-lined streets on residential real estate value $[43,44]$ and on commercial activity in business districts [45]. As cities initiate sustainability plans and move towards more green, blue, and turquoise infrastructure designs, society will need a larger urban natural infrastructure management workforce. Many cities have embarked on widespread tree planting and green infrastructure initiatives, with the need for ongoing maintenance by professionals [46-49]. With a growing interest in new green, blue, and turquoise infrastructure, urban environmental restoration and maintenance jobs offer an opportunity for those with limited formal education or specialized job training to establish what are broadly referred to as "green-collar" careers. Furthermore, engaging in environmental restoration work may provide benefits to workers beyond simple employment, including exposure to and interactions with nature [50], which is a limited "commodity" in many urban locations. In short, cities are habitat for people, so the urban design process should include city residents and integrate a social component into design objectives and actions.

Green and blue infrastructure are familiar concepts and features of cities. These two terms, and color designations, delineate services provided by terrestrial versus aquatic urban ecological features and ecosystems. But these two infrastructure designations may not cover all urban ecological features and associated services. For example, urban wetlands are an important component of "natural" infrastructure in virtually all cities. While some urban wetlands are found in, or have been rehabilitated to be in, somewhat natural states, many of these wetland systems were designed and constructed to provide specific services. These services include wastewater treatment, stormwater management, recreation and aesthetics, and habitat. Wetlands are found where terrestrial and aquatic ecosystems meet, and are considered ecotone ecosystems. They have ecological functions and structures that are both terrestrial and aquatic in character [51]. As such, urban wetlands are both green and blue infrastructure. When one combines green and blue, the result is the color turquoise. Thus, we posit that urban wetlands are unique enough in the urban matrix to warrant the term "turquoise infrastructure".

Box 1. The Colors of Urban Design: Turquoise Infrastructure.

\section{Moving from an Ecology of Cities to an Ecology for Cities}

Calls for improved integration of ecological knowledge with the theory and practice of urban design are decades old [52,53], including those from the UNESCO Man and the Biosphere Program (e.g., [54,55]). Yet successful integration is rare and is concentrated in a few institutions and opportunities [56-58]. We argue that there is a pressing need to institutionalize these interdisciplinary connections and to extend their scope. Sustaining both human well-being and the integrity of the biosphere continues to be a test of public decision-making and institutions, and a major challenge to the academy and its linkages to civic processes. The scope of this challenge is daunting because of the complexity of sustainability, whose three pillars - environment, society, and economy-encompass many dimensions, including social values, ethics, equity, justice, connectedness and heritage, ecological integrity, and economic viability. Our argument for and approach to a transformational design-ecology nexus is also a call for us to move from an ecology of cities, as described by Pickett et al. [19] and 
Grimm et al. [20], to an ecology for cities where urban ecologists, designers, planners, engineers, residents, and others are actively pursuing a more sustainable future (per [3]).

If sustainability is a socially-generated process, then social-ecological resilience is its mechanism [3]. Resilience as a theory highlights the need for understanding how complex adaptive systems develop and evolve, the role of disturbance and disruption, the drivers of collapse of complex social-ecological systems, the nature of reorganization after collapse, and the various modes of adaptation that permit reorganization [59-61]. However, standard resilience theory has largely neglected an explicit consideration of design, and both its intended and unintended consequences, and instead has focused on the more comfortable realm of policy and management. Thus, we need an improved understanding of urban sustainability that extends beyond the founding concerns of resilience theory with natural resources management to include the design process. The design realm often focuses on resilience as a socially- or politically-driven desire to build back after some disaster [62]. This is an important step, and additional analyses of resilience, such as those focused on transportation and associated urban form [63] exemplify additional steps. This transformative integration is required to achieve urban systems resilience, particularly in the face of extreme conditions, such as heat, drought, and floods. In the next section we describe a model for this transformation.

\section{A Model for Transforming the Urban Design-Ecology Nexus}

Merely positing that a transformational change needs to occur is insufficient if positive outcomes are the goal. Thus, we present a model for how to advance an urban design-ecology nexus to meet the complex needs of cities facing a future of change and uncertainty. We propose that any model needs to have certain performance features. It needs to be flexible so that ecological boundaries - as spaces of action - can change and diversify, mirroring everyday environmental realities. It needs to be adaptive, inclusive, and responsive to our increasingly inequitable societies and human migrations. And it needs to be future thinking in ways that value diverse forms of imagination and communication - for example, drawing has a powerful role in capturing a shared sense of future possibilities [64]. These features of an urban design-ecology approach will substantially improve the capacity of urbanized jurisdictions and urban regions to improve their sustainability plans and actions. Our focus on extreme events, exemplified primarily by heat waves, drought, and floods, turns the attention of the design and policy-making communities to conditions that are not always present, but that nonetheless are important for making sustainable urban designs flexible and adaptable. Because design addresses many spatial scales, myriad clients, and is situated in a diversity of land covers and neighborhoods, engaging ecological science will vastly enhance the effectiveness of both the design process and of urban ecology [65].

First and foremost, our model is inclusive and involves all requisite parties in the urban design process (Figure 1B). As we noted in the section above, this transdisciplinary design process should include urban social and ecological scientists, landscape architects, city residents, and students of all related disciplines in addition to professional architects, engineers, and planners. A key contrast between our model and the status quo (Figure 1A) is that our model of the design process is non-linear and includes critical feedbacks, throughout the process, among key stakeholders, urban ecological research, and knowledge derived from previous projects [39]. In terms of sustainability science, this is 
the co-production or co-generation of urban design [66] that is manifest by providing a collaborative environment for urban designs to be envisioned and implemented $[67,68]$.

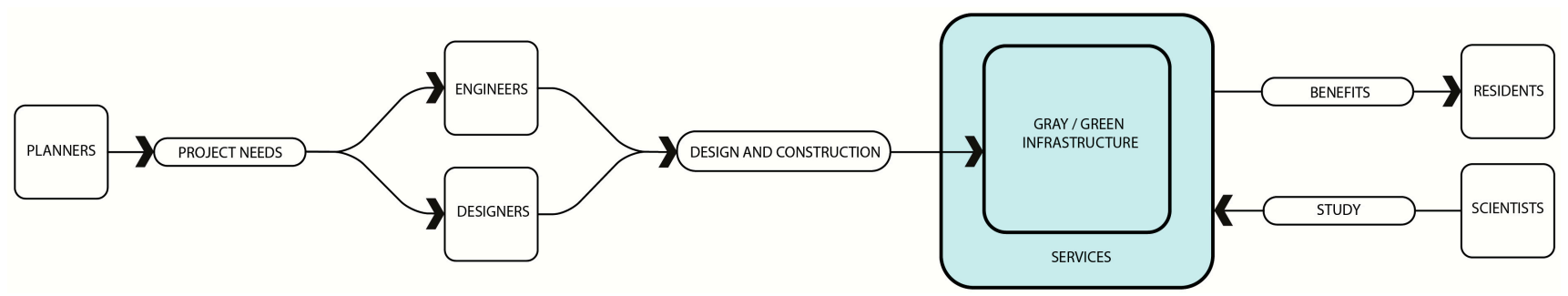

(A)

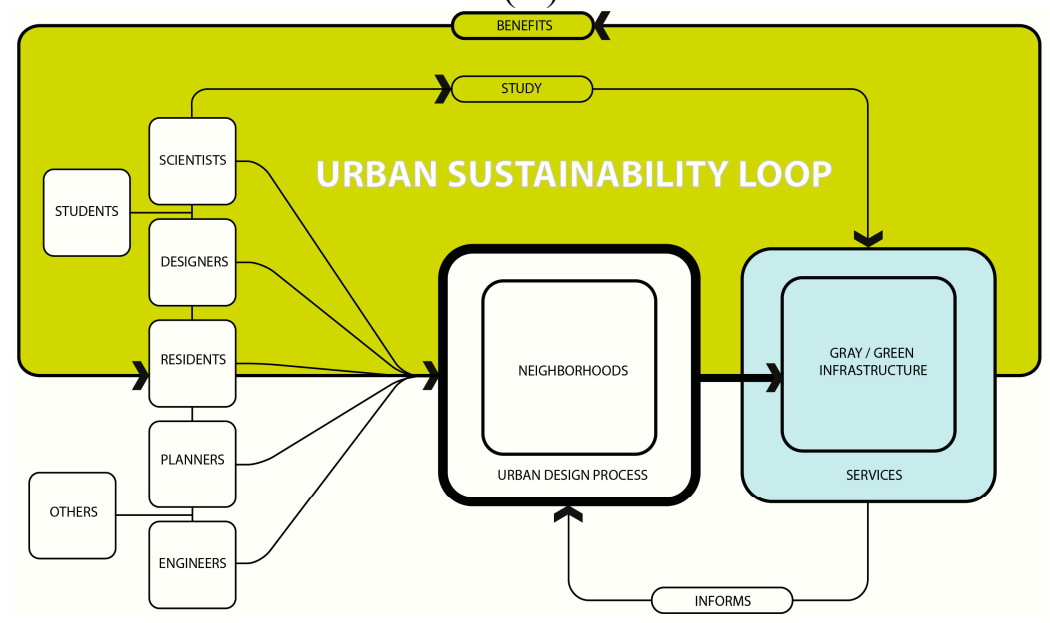

(B)

Figure 1. (A) (Top): The typical way in which urban infrastructure is conceived, designed, constructed, and evaluated. Focus is often on only one or a few services and the process is linear; (B) (Bottom): The integrated approach, proposed here, for implementing urban infrastructure in which the design is co-produced in a transdisciplinary way, and the infrastructure is designed to provide multiple services. This approach is not linear; rather, it has several key feedback loops that we show as contained in an "urban sustainability loop"; this loop is highlighted in yellow for emphasis. Note that "Scientists" includes urban social and ecological scientists and "Others" may include elected officials, business leaders, famous individuals, powerful interest groups, etc.

Cities are designed to be human habitat, and as such Homo sapiens are the "ecosystem engineers" [69] of urban systems. No attempt to create a new, transformative, integrated approach to urban design can be successful without fully considering the social structures and dynamics of the city [57], including those that are value-laden and normative [70]. Paying attention to the well-being of populations that have been historically overburdened by environmental hazards and excluded from policy and planning decisions is also crucial in the design of sustainable and equitable cities and regions [54]. For this reason equity is a key tenet of sustainability [1,71,72]. A transformative urban design process must incorporate justice and equity [73], and strategies for doing so should be informed by history, including socio-spatial analyses of patterns of settlement, displacement, and segregation of vulnerable populations, and the policy and planning procedures that shaped those patterns [74]. 
Urban governance is defined as a mode of public decision-making that involves public, private, and non-profit actors at all levels of city management [75]. Governance theory can be used as an organizing framework to examine and understand macro-scale shifts from top-down state-centered approaches towards more interactive policy-making processes and hybrid arrangements that involve diverse interactions among multiple social actors [76-78]. In the context of urban environmental governance, a shift towards multi-sector activities can be a response to climate change uncertainty and a management strategy for enabling robust urban ecosystem services as well as systemic adaptation and resilience [79-81].

While urban planners and policy-makers have long addressed environmental issues, the constellation of groups associated with the governance of urban ecological processes has shifted in recent decades from hierarchical to polycentric structures [82-86]. In many cities, urban environmental stewardship groups have become an essential component of governance that regulates ecosystem services [87]. These groups include organizations that work to conserve, manage, monitor, advocate for, or educate about a range of quality-of-life issues regarding urban resources. They include community development groups focused on environmental issues and environmental groups focused on community-based quality-of-life issues [88]. Taken together, these constellations of civic groups can form a large component of novel urban governance systems and can be important stakeholders in our transformational model for the urban design process [89].

Designers can choose to locate their work within democratic politics in a range of modes. The consensus mode, as an ideal, is sometimes not realizable. In addition, it has been criticized for being hegemonic when there is no possibility of final reconciliation. In these situations designers can work in an agonistic mode of democratic politics by visualizing that which is repressed and destroyed by the consensus of post-political democracy [90], and expanding capacities for collective production and self-governance [89].

As we noted earlier, our model for a transformative urban design-ecology nexus is future-oriented and anticipatory. For this reason, a critical component of our model is creative visioning. Transformation does not happen instantaneously. Thus, any evolution of the urban design process must involve the education and training of a cadre of: (1) ecologically literate urban designers and engineers; (2) design-literate, engineering-conscious ecologists; (3) broad-thinking and holistically inclined planners, and; (4) place-aware and activist city residents. There are myriad ways to accomplish these educational goals [33,90], using both place-based and virtual approaches. Interdisciplinary design studios, workshops, community charrettes, and teaching are all critical, and may be facilitated by Internet-based interactions. This may be particularly valuable for facilitating interactions with government or non-profit employees who may find it difficult to travel to face-to-face studios or charrettes. Although direct interactions may be quite valuable, virtual interactions can also facilitate the contributions of community members in design processes that bring together experts from distant locations who might not otherwise be able to participate. Furthermore, virtual interactions can be digitally archived and used again, thus allowing activities to be virtual in both space and time. Our model does not intend to be prescriptive about the specifics, as long as transformative goals, inclusiveness, and a focus on the future are central to the approach. One might imagine that place-based "transformative design studios" would be located at academic institutions or at larger design firms, with strong connections to local planners and community members. A more ambitious approach would 
network and integrate a number of these inclusive, place-based studios across cities, with virtual connections to each other and to planning and to decision-making entities in their respective cities.

Regardless of the approach, it is critical that these "transformative design studios" or "arenas of inclusive design" produce: (1) methodologies for rigorously assessing the effectiveness of ecologically-informed designs both on the "drawing board" and in the field; (2) platforms for the transdisciplinary sharing of sustainable ecological design insights; (3) lasting institutional and organizational collaborations, preferably across a spectrum of climatic conditions for the inter-city networks, to maintain these efforts; and (4) an expansion of general theories of inclusive urbanism [17,26,91,92]. This integrated network of students, community members and leaders, graduates, scientists, and teachers should connect across the nation, and ultimately the globe. But at the same time they must engage their local institutions and government agencies that have a history of acting in isolation despite the growing calls for sustainable urban design, revitalization, and regional integration. In short, our ambition for a transformational urban design-ecology nexus has the ultimate goal of changing the way cities are designed, managed, and inhabited based on a deeper social, ecological, technological, and political understanding of urban sustainability and of the urban experience.

\section{Examples of Challenges and Successes}

Fine-scale experimental urban design provides a unique opportunity to explore transformative new approaches to the design process $[93,94]$. In our inclusive model for transforming the urban design process (Figure 1), all players involved in design would also be continually involved in these on-the-ground design initiatives or experiments. As such, our model includes both the co-production of design and the co-production of knowledge through design experimentation, all happening in a safe space - real or virtual-for collaboration and communication. Below we briefly describe several case studies in which this co-production approach has been attempted or used successfully.

A. Goodyear AZ USA: This project was focused on an experimental streetscape project that was initiated at the behest of city planners from the City of Goodyear, AZ, USA. A team of urban ecologists, landscape architects and students, and social scientists was assembled to design and implement four streetscape options with differing landscaping, water use, and microclimate impacts. The streetscape was to be built on a $25 \mathrm{~m} \times 750 \mathrm{~m}$ plot of vacant land along Goodyear's main boulevard, near City Hall (Figure 2). City planners and community members from an adjacent historic neighborhood provided ideas on and local knowledge that informed designs drafted by an upper division landscape architecture studio class at Arizona State University. Prior to construction of the experimental streetscape, data were to be collected on human-scale microclimate to quantify physical characteristics that relate to people's perceptions of their immediate climate (Figure 3). Educational signage was planned to keep the neighborhood and users of this unique streetscape park updated on new findings and project progress, and residents were to be periodically be surveyed about their project-related perceptions and values. After the project was constructed, biophysical and social monitoring were to continue to quantitatively identify the best, and most desirable, streetscape designs, as well as the success of the park as an education and outreach tool. This project should have been a showcase example of how integrating ecology, design, social science, and policy moves us from an ecology of cities to an 
ecology for cities (per [3]). Unfortunately, the entire project was ultimately cancelled after more than a year of negotiations between City officials, the landowner, and lawyers. The park was to be located on the edge of a remediated Superfund site, and the legal challenges associated with this finally made the project untenable. As this paper was published, City officials were looking for another site for the park. This is an example of the challenges that can be faced when trying to implement our transdisciplinary ecology-design nexus model.

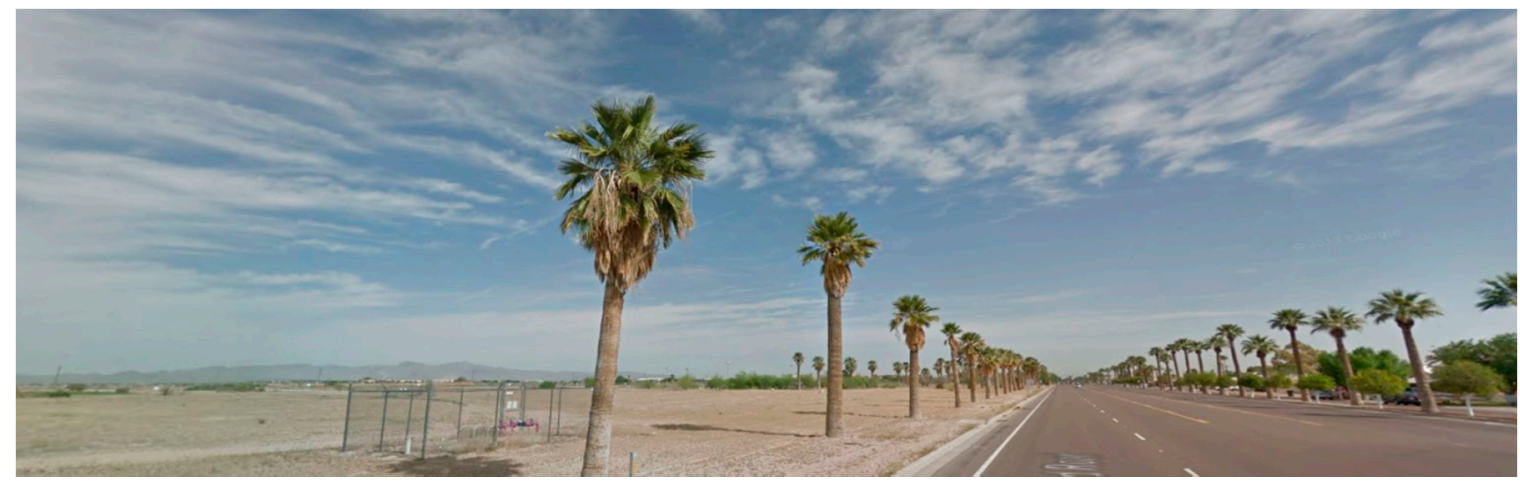

Figure 2. Street view of the property in Goodyear, AZ, USA where the experimental demonstration streetscape will be constructed. The park was to be on the left and the historical neighborhood is on the extreme right (photo credit: D. Childers).

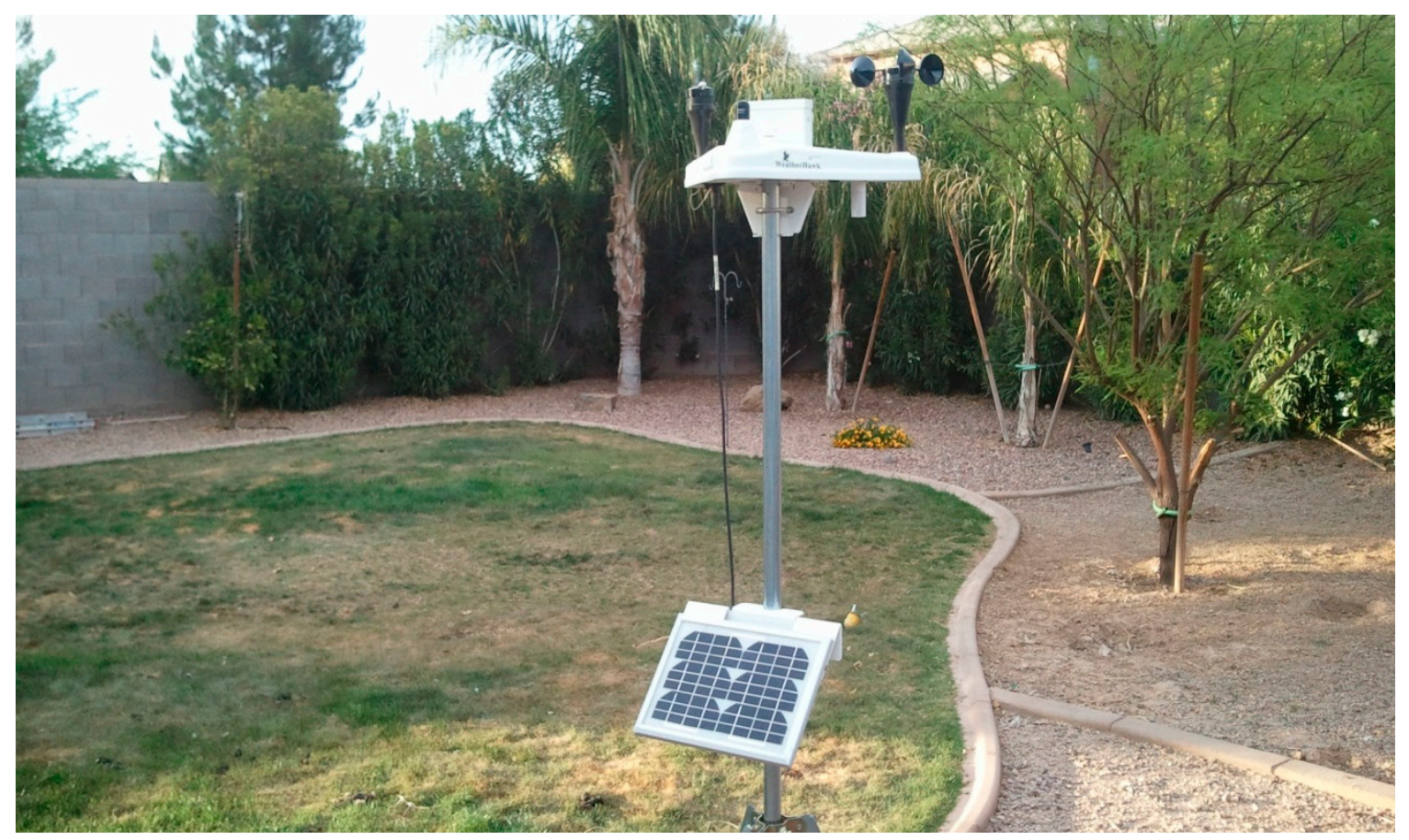

Figure 3. Micrometeorological towers used to monitor variables related to people's perceptions of their immediate climate. Towers include sensors that measure air temperature, relative humidity, wind speed, and light at $2 \mathrm{~m}$ height, as well as soil temperature, soil moisture, and irrigation water use (photo credit, B. Ruddell).

B. Baltimore MD USA: Over ten years, academic urban design studios have been instrumental in building a dialogue about sustainable urban development between scientific research by the 
Baltimore Ecosystem Study Long-Term Ecological Research Program (BES LTER) and local non-profit and government organizations. The urban design-ecology nexus developed by the BES LTER Urban Design Working Group (UDWG) connects the neighborhood scale of urban design practice with the ecological theory of patch dynamics. Urban neighborhoods in the Baltimore region are distinct land-cover neighborhood patches within larger watershed and human ecosystem frameworks. Early studios organized by the BES UDWG focused on connecting the emerging social infrastructure of the Gwynns Falls trail system to new urban land cover and hydrological data [95]. This work, based on an open urban stream network, continued in the underground piped Watershed 263 in West Baltimore [96]. It also included proposals for the redevelopment of the Middle Branch waterfront with the office of Baltimore City Planning. More recently design studios with the Baltimore Office of Sustainability and two neighborhood groups-The Harlem Park Neighborhood Association/Parks and People and the Historic East Baltimore Action Coalition-provided examples of how ecosystem science can be integrated with local grassroots efforts to rejuvenate neighborhoods suffering from disinvestment. Working with vacant lots and unused city space, social capital and job generation were a critical part of these green and blue infrastructure proposals. Examples of the resulting designs can be found at [97,98]

C. The Urban Complex, NJ USA: Between 2002 and 2010, the urban design and landscape architecture firm Till Design undertook two client-based, professional-practice, brownfield redevelopment projects. The first, Monroe Center for the Arts, includes an art community in two old factory buildings and two new buildings surrounded by a plaza on two blocks located on a former wetland on the western edge of Hoboken, NJ. The second, Celadon, is a new high-rise, high-density, transit-oriented, mixed-use development located on a municipal dump on Newark Bay, in Elizabeth NJ. In both projects, urban ecology informed the design in three ways to increase the economic, cultural, and environmental value of the projects:

(1) The inclusion of green infrastructure such as stormwater features, roof gardens, vegetated plazas, and waterfront promenades.

(2) The inclusion of a phased approach where micro-scale social-ecological engagement was supported from the very start of the project. This allowed the project to debut publicly, with elements such as a drawing club on a parking lot, a temporary film garden, a low-tech kayak launch, and a sound game. Other elements included fountains, roof gardens accessible by public elevators, the co-production of a "bay music" sound signature, and a ferry to Manhattan.

(3) The inclusion of innovative financing in short, medium, and long concurrent cycles that were designed and launched to allow both of these environmentally activist real-estate development to happen $[99,100]$.

D. Sacramento, CA, USA: The Building Healthy Communities site in Sacramento, CA has embarked upon a process of community planning in order to engage residents and develop comprehensive and inclusive neighborhood action plans that inform advocacy. Building Healthy Communities is a program of the California Endowment, a private, state-wide health organization that aims to improve the health status of all Californians by considering what happens outside of the doctor's office and beyond people's individual choices. In 2010, the California Endowment initiated a 10-year initiative called Building Healthy Communities (BHC). It chose 14 cities for its initial application 
based on the health status and challenges to health faced by the residents of these cities and on the potential to inspire broader policy changes that could create healthier environments. The Sacramento BHC consists of nearly 20 small neighborhoods spanning both incorporated and unincorporated areas of South Sacramento. More than 65,000 residents call the Sacramento BHC home. While these residents experience high rates of economic, educational, and health challenges, they also are represented by engaged and supportive elective officials. The residents are served by many active and collaborative grassroots advocacy organizations working to address these disparities. In 2014, a collection of organizations, led by the non-profit organization Ubuntu Green, held a series of events that culminated in a week-long charrette, engaging residents to develop community action plans around several issues including access to healthy food, economic development and housing, pedestrian and bike safety, and environmental health. Residents could participate in person or by responding to Internet-based surveys and commenting on social media outlets. All materials were presented in three languages and events ran through the day and into the evening, providing as much time as possible for participation. The resulting community action plans will be released in early 2015 and will be used to inform advocacy for the organizations and resident groups associated with the BHC.

\section{Summary}

Urban development takes a wide variety of forms around the world, from the older, traditional compact city, to the bustling metropolis of the 19th and 20th century, to the low density car-based exurb, to the informal megacity. Cities of all forms would benefit from the transformative nexus of ecology and design that we propose here in order to advance climate change resilience and enhance future sustainability. This design-ecology nexus does not prescribe a narrow range of solutions for green design or urban sustainability; rather, it is a transdisciplinary process of reiteration, feedbacks, deliberation, and debate between social and natural systems. An ecology for cities is a call for action-based ecological research and knowledge that is part of a new urban design process working at all scales of urban decision-making, from individual households to neighborhoods to regions. We argue that this inclusive, creative process will produce new and innovative solutions that will allow tomorrow's cities to be better prepared for a climate-uncertain future.

\section{Acknowledgments}

The authors of this paper are members of the Urban Sustainability Research Coordination Network that is supported by the U.S. National Science Foundation (NSF) through Grant No. 1140070. Additional support has been provided by the NSF to DLC through the CAP LTER Program (Grant No. 1026865), to MLC, JMG, BM, and STAP through the BES LTER Program (Grant No. 1027188), and to MLC through Grant No. 0844778.

\section{Author Contributions}

All authors contributed substantially to the ideas, concepts, and work presented in this paper. All authors were also involved in the preparation of the manuscript and have approved the submitted form. 


\section{Conflicts of Interest}

The authors declare no conflict of interest.

\section{References}

1. Gibson, R.B. Beyond the pillars: Sustainability assessment as a framework for effective integration of social, economic, and ecological considerations in significant decision-making. J. Environ. Assess. Policy Manag. 2006, 8, 259-280.

2. Leach M.; Scoones, I.; Stirling, A. Dynamic Sustainabilities: Technology, Environment, Social Justice; Earthscan: New York, NY, USA, 2010.

3. Childers, D.L.; Pickett, S.T.A.; Grove, J.M.; Ogden, L.; Whitmer, A. Advancing urban sustainability theory and action: Challenges and opportunities. Landsc. Urban Plan. 2014, 125, 320-328.

4. Pickett, S.T.A.; Boone, C.G.; McGrath, B.P.; Cadenasso, M.L.; Childers, D.L.; Ogden, L.A.; McHale, M.; Grove, J.M. Ecological science and transformation to the sustainable city. Cities 2013, 32, S10-S20.

5. Papaneck, V. Design for the Real World: Human Ecology and Social Change; Academy Chicago Publishers: Chicago, IL, USA, 2005.

6. Thackara, J. In the Bubble: Designing for a Complex World; The MIT Press: Cambridge, UK, 2006.

7. Huang, G.L.; Zhou, W.Q.; Cadenasso, M.L. Is everyone hot in the city? Spatial pattern of land surface temperatures, land cover and neighborhood socioeconomic characteristics in Baltimore, MD. J. Environ. Manag. 2011, 92, 1753-1759.

8. Milly, P.C.D.; Betancourt, J.; Falkenmark, M.; Hirsch, R.M.; Kundzewicz, Z.W.; Letternaier, D.P.; Stouffer, R.J. Stationarity is dead: Whither water management. Science 2008, 319, 573-574.

9. Platt, R.H.; Rowntree, R.A.; Muick, P.C. Sustainability in urban ecosystems: Beyond an object of study. In The Ecological City: Preserving and Restoring Urban Biodiversity; University of Massachusetts-Amherst Press: Amherst, MA, USA, 1994; pp. 49-65.

10. Hunt, D.V.L.; Rogers, C.D.F. A Benchmarking System for Domestic Water Use. Sustainability 2014, 6, 2993-3018.

11. Tingstad, A.H.; Groves, D.G.; Lempert, R.J. Paleoclimate Scenarios to Inform Decision Making in Water Resource Management: Example from Southern California's Inland Empire. J. Water Res. Plan. Manag. 2014, 140, 04014025.

12. Desimini, J. Civic space in regional frameworks: Resilient approaches to urban design. In Resilience in Ecology and Urban Design: Linking Theory and Practice for Sustainable Cities; Pickett, S.T.A., Cadenasso, M.L., McGrath, B., Eds.; Springer: New York, NY, USA, 2013; pp. 307-318.

13. Shannon, K. Eco-engineering for water: From soft to hard and back. In Resilience in Ecology and Urban Design: Linking Theory and Practice for Sustainable Cities; Pickett, S.T.A., Cadenasso, M.L., McGrath, B., Eds.; Springer: New York, NY, USA, 2013; pp. 163-182. 
14. Adaman, F. Power inequalities in explaining the link between natural hazards and unnatural disasters. Dev. Chang. 2012, 43, 395-407.

15. McGrath, B. Urban Design Ecologies; John Wiley \& Sons: London, UK, 2012.

16. Tanner, C.J.; Adler, F.R.; Grimm, N.B.; Groffman, P.M.; Levin, S.A.; Munshi-South, J.; Pataki, D.E.; Pavao-Zucherman, M.; Wilson, W.G. Urban ecology: Advancing science and society. Front. Ecol. Environ. 2014, 21, 574-581.

17. Pickett, S.T.A.; Cadenasso, M.L.; McGrath, B. Resilience in Ecology and Urban Design: Linking Thoery and Practice for Sustainable Cities; Springer: New York, NY, USA, 2013; p. 499.

18. United Nations. World Urbanization Prospects: The 2011 Revision Highlights; United Nations: New York, NY, USA, 2012; p. 50.

19. Pickett, S.T.A.; Burch, W., Jr.; Dalton, S.; Foresman, T.W.; Rowntree, R. A conceptual framework for the study of human ecosystems in urban areas. Urban Ecosyst. 1997, 1, 185-199.

20. Grimm, N.B.; Grove, J.M.; Pickett, S.T.A.; Redman, C.L. Integrated approaches to long-term studies of urban ecological systems. BioScience 2000, 50, 571-584.

21. Shane, D.G. Urban Design since 1945: A Global Perspective; John Wiley \& Sons: London, UK, 2011.

22. McHarg, I. Design with Nature; The Natural History Press: New York, NY, USA, 1969.

23. Forman, R.T. Land Mosaics: The Ecology of Landscapes and Cities; Cambridge University Press: Cambridge, UK, 1995.

24. Waldheim, C. Landscape Urbanism; Princeton Architectural Press: New York, NY, USA, 2006.

25. Mostafavi, M.; Doherty, G. Ecological Urbanism; Lars Muller: Zürich, Switzerland, 2010.

26. Spirn, A.W. Ecological Urbanism: A Framework for the Design of Resilient Cities. Available online: http://www.annewhistonspirn.com/pdf/Spirn-EcoUrbanism-2012.pdf (accessed on 1 November 2012).

27. Seto, K.C.; Reenberg, A.; Boone, C.G.; Fragkias, M.; Haase, D.; Langanke, T.; Marcotullio, P.; Munroe, D.K.; Olah, B.; Simon, D. Urban land teleconnections and sustainability. Proc. Natl. Acad. Sci. USA 2012, 109, 7687-7692.

28. Boone, C.G.; Redman, C.L.; Blanco, H.; Haase, D.; Koch, J.; Lwasa, S.; Nagendra, H.; Pauleit, S.; Pickett, S.T.A.; Seto, K.C.; et al. Reconceptualizing land for sustainable urbanity. In Rethinking Urban Land Use in a Global Era; Seto, K.C., Reenberg, A., Eds.; MIT Press: Cambridge, UK, 2014; pp. 313-330.

29. Newman, P.; Jenkins, I. Cities As Sustainable Ecosystems: Principles and Practices; Island Press: Washington, DC, USA, 2008.

30. Larson, E.K.; Earl, S.; Hagen, E.M.; Hale, R.; Hartnett, H.; McCracken, M.K.; McHale, M.; Grimm, N.B. Beyond restoration and into design: Hydrological alterations in aridland cities. In Resilience in Ecology and Urban Design: Linking Theory and Practice for Sustainable Cities; Pickett, S.T.A., Cadenasso, M.L., McGrath, B., Eds.; Springer: New York, NY, USA, 2013; pp. 183-210.

31. Novotny, V. Water-energy nexus: Retrofitting urban areas to achieve zero pollution. Build. Res. Inf. 2013, 45, 489-604. 
32. Sze, J.; Gambirrazio, G. Eco-cities without ecology: Constructing ideologies, valuing nature. In Resilience in Ecology and Urban Design: Linking Theory and Practice for Sustainable Cities; Pickett, S.T.A., Cadenasso, M.L., McGrath, B., Eds.; Springer: New York, NY, USA, 2013; pp. 289-297.

33. Bargmann, J. Just ground: A social infrastructure for urban landscape regeneration. In Resilience in Ecology and Urban Design: Linking Theory and Practice for Sustainable Cities; Pickett, S.T.A., Cadenasso, M.L., McGrath, B., Eds.; Springer: New York, NY, USA, 2013; pp. 347-354.

34. Melosi, M.V. The sanitary city: Urban Infrastructure in America from Colonial Times to the Present; Johns Hopkins University Press: Baltimore, MD, USA, 2000; p. 600.

35. Ahern, J. From fail-safe to safe-to-fail: Sustainability and resilience in the new urban world. Landsc. Urban Plan. 2011, 100, 341-343.

36. Fiksel, J. Sustainability and resilience: Toward a systems approach. Sustain. Sci. Pract. Policy 2006, 2, 14-21.

37. Anderies, J.M.; Janssen, M.A. Robustness of social-ecological systems: Implications for public policy. Policy Stud. J. 2013, 41, 513-536.

38. Beatley, T. Green urbanism: Learning from European cities; Island Press: Washington, DC, USA, 2000; p. 491.

39. Felson, A.J. The design process as a framework for collaboration between ecologists and designers. In Resilience in Ecology and Urban Design: Linking Theory and Practice for Sustainable Cities; Pickett, S.T.A., Cadenasso, M.L., McGrath, B., Eds.; Springer: New York, NY, USA, 2013; pp. 365-382.

40. Glover, T.D.; Shinew, K.J.; Parry, D.C. Association, sociability, and civic culture: The democratic effect of community gardening. Leis. Sci. 2005, 27, 75-92.

41. Svendsen, E. Cultivating resilience: Urban stewardship as a means to improving health and well-being. In Restorative Commons: Creating Health and Well-Being through Urban Landscapes; Campbell, L., Wiesen, A., Eds.; General Technical Report; U.S. Department of Agriculture, Forest Service, Northern Research Station: Newtown Square, PA, USA, 2009; pp. 58-87.

42. Peters, K.; Elands, B.; Buijs, A. Social interactions in urban parks: Stimulating social cohesion? Urban For. Urban Green. 2010, 9, 93-100.

43. Morales, D.J. The contribution of trees to residential property value. J. Arbor. 1980, 6, 305-308.

44. Anderson, L.M.; Cordell, H.K. Influence of trees on residential property values in Athens, Georgia (USA): A survey based on actual sales prices. Land. Urban Plan. 1988, 15, 153-164.

45. Wolf, K. Business district streetscapes, Trees and consumer response. J. For. 2005, 103, 396-400.

46. Baltimore Center for Green Careers. Available online: http://www.baltimoregreencareers.org (accessed on 12 March 2015).

47. City of Los Angeles. Million Trees LA. Available online: http://www.milliontreesla.org/ mtabout1.htm (accessed on 12 March 2015).

48. City of Seattle. City of Seattle Comprehensive Plan. Available online: http://www.seattle.gov/ dpd/Planning/Seattle_s_Comprehensive_Plan/ComprehensivePlan/(accessed on 12 March 2012). 
49. City of Phoenix. Tree and Shade Master Plan. Available online: https://www.phoenix.gov/ parkssite/Documents/T\%20and\%20A\%202010.pdf (accessed on 12 March 2015).

50. Falxa-Raymond, N.; Svendsen, E.; Campbell, L.K. From job training to green jobs: A case study for a young adult employment program centered on environmental restoration in New York City, USA. Urban For. Urban Green. 2013, 12, 287-295.

51. Mitsch, W.J.; Gosselink, J.G. Wetlands: Third Edition; John Wiley and Sons: New York, NY, USA, 2000.

52. Spirn, A.W. The Granite Garden: Urban Nature and Human Design; Basic Books: New York, NY, USA, 1984.

53. Steiner, F. Urban landscape perspectives. Landsc. Urban Plan. 2014, 3, 342-350.

54. Di Castri, F.; Baker, F.; Hadley, M. The Man and the Biosphere Program as an Evolving System. Ambio 1981, 10, 52-57.

55. Boyden, S.; Millar, S.; Newcombe, K.; O’Neill, B. The Ecology of a City and Its People: The Case of Hong Kong; Australian National University Press: Canberra, Australia, 1981.

56. Pickett, S.T.A.; McGrath, B.; Cadenasso, M.L. The ecology of the metacity: Shaping the dynamic; patchy, networked, and adaptive cities of the future. In Resilience in Ecology and Urban Design: Linking Theory and Practice for Sustainable Cities; Pickett, S.T.A., Cadenasso, M.L., McGrath, B., Eds.; Springer: New York, NY, USA, 2013; pp. 463-489.

57. Boone, C.G. Social dynamics and sustainable urban design. In Resilience in Ecology and Urban Design: Linking Theory and Practice for Sustainable Cities; Pickett, S.T.A., Cadenasso, M.L., McGrath, B., Eds.; Springer: New York, NY, USA, 2013; pp. 47-61.

58. Grove, J.M. Ecological and social linkages in urban design projects: A synthesis. In Resilience in Ecology and Urban Design: Linking Theory and Practice for Sustainable Cities; Pickett, S.T.A., Cadenasso, M.L., McGrath, B., Eds.; Springer: New York, NY, USA, 2013; pp. 355-360.

59. Holling, C.S. Cross-scale morphology, geometry, and dynamics of ecosystems. Ecol. Monogr. 1992, 62, 447-502.

60. $\mathrm{Wu}, \mathrm{J} . ; \mathrm{Wu}, \mathrm{T}$. Ecological resilience as a foundation for urban design and sustainability. In Resilience in Ecology and Urban Design: Linking Theory and Practice for Sustainable Cities; Pickett, S.T.A., Cadenasso, M.L., McGrath, B., Eds.; Springer: New York, NY, USA, 2013; pp. 211-229.

61. Pickett, S.T.A.; McGrath, B.; Cadenasso, M.L.; Felson, A.J. Ecological resilience and resilient cities. Build. Res. Inf. 2014, 42, 143-157.

62. Vale, L.J.; Campanella, T.J. The Resilient City: How Modern Cities Recover from Disaster; Oxford University Press: New York, NY, USA, 2005; p. 376.

63. Newman, P.; Beatley, T.; Boyer, H. Resilient Cities: Responding to Peak Oil and Climate Change; Island Press: Washington, DC, USA, 2009.

64. Marshall, V. Ecological Urban Design Visuality and Landscape. Nakhara J. Environ. Des. Plan. 2014, 10, 113-126.

65. Felson, A.J.; Bradford, M.A.; Terway, T.M. Promoting Earth Stewardship through urban design experiments. Front. Ecol. Environ. 2013, 11, 362-367.

66. Schellnhuber, H.J.; Crutzen, P.J.; Clark, W.C.; Hunt, J. Earth system analysis for sustainability. Sci. Policy Sustain. Dev. 2005, 47, 11-25. 
67. Lemos, M.C.; Morehouse, B.J. The co-production of science and policy in integrated assessments. Glob. Environ. Chang. 2005, 15, 57-68.

68. Robinson, J.; Tansey, J. Co-production, emergent properties and strong interactive social research: The Georgia Basin Futures Project. Sci. Public Policy 2006, 33, 151-160.

69. Lawton, J.H.; Jones, C.G. Linking species and ecosystems: Organisms as ecosystem engineers. In Linking Species and Ecosystems; Jones, C.G., Lawton, J.H., Eds.; Chapman and Hall: New York, NY, USA, 1995; pp. 141-150.

70. Rozzi, R.; Pickett, S.T.A.; Palmer, C.; Callicott, J.B. Linking Ecology and Ethics for a Changing World: Values, Philosophy, and Action; Springer: New York, NY, USA, 2014.

71. Agyeman, J.; Evans, T. Toward just sustainability in urban communities: Building equity rights with sustainable solutions. Ann. Am. Acad. Polit. Soc. Sci. 2003, 590, 35-53.

72. Agyeman, J. Sustainable Communities and the Challenge of Environmental Justice; NYU Press: New York, NY, USA, 2005.

73. Pickett, S.T.A.; Buckley, G.L.; Kaushal, S.S.; Williams, Y. Social-ecological science in the humane metropolis. Urban Ecosyst. 2011, 14, 319-339.

74. Lord, C.H.; Norquist, K. Cities as Emergent Systems: Race as a Rule in Organized Complexity. Environ. Law 2010, 40, 551-597.

75. Stoker, G. Governance as theory: Five propositions. Int. Soc. Sci. J. 1998, 50, 17-28.

76. Rhodes, R.A.W. The new governance: Governing without government. Polit. Stud. 1996, 44, 652-667.

77. Jordan, A. The governance of sustainable development: Taking stock and looking forwards. Environ. Plan. C Govern. Policy 2008, 26, 17-33.

78. Fisher, D.; Svendsen, E. Hybrid arrangements within the environmental state. In Routledge International Handbook of Social and Environmental Change; Lockie, S., Sonnenfeld, D., Fisher, D., Eds.; Routledge: London, UK, 2014; pp. 179-189.

79. Bulkeley, H.; Betsill, M. Cities and Climate Change: Urban Sustainability and Global Environmental Governance; Routledge: New York, NY, USA, 2003.

80. Adger, W.N.; Arnell, N.W.; Tompkins, E.L. Successful adaptation to climate change across scales. Glob. Environ. Chang. 2005, 15, 77-86.

81. Daily, G.C.; Polasky, S.; Goldstein, J.; Kareiva, P.M.; Mooney, H.A.; Pejchar, L.; Ricketts, T.H.; Salzman, J.; Shallenberger, R. Ecosystem services in decision making: Time to deliver. Front. Ecol. Environ. 2009, 7, 21-28.

82. Weber, E.P. A new vanguard for the environment: Grass-roots ecosystem management as a new environmental movement. Soc. Natl. Resour. 2000, 13, 237-259.

83. Kempton, W.; Holland, D.C.; Bunting-Howarth, K.; Hannan, E.C. Local environmental groups: A systematic enumeration in two geographical areas. Rural Sociol. 2001, 66, 557-578.

84. Sirianni, C.; Friedland, L. Civic Innovation in America: Community Empowerment, Public Policy, and the Movement for Civic Renewal; University of California Press: Berkeley, CA, USA, 2001.

85. Andrews, K.T.; Edwards, B. The organizational structure of local environmentalism. Mobiliz. Int. Quart. 2005, 10, 213-234. 
86. Svendsen, E.S.; Campbell, L.K. The Urban Ecology Collaborative Assessment: Understanding the Structure, Function, and Network of Local Environmental Stewardship; U.S.D.A. Forest Service Northern Research Station: New York, NY, USA, 2005.

87. Ernstson, H.; Sorlin, S.; Elmqvist, T. Social movements and ecosystem services-The role of social network structure in protecting and managing urban green areas in Stockholm. Ecol. Soc. 2008, 13, Article 39.

88. Fisher, D.R.; Campbell, L.K.; Svendsen, E.S. The organizational structure of urban environmental stewardship. Environ. Polit. 2012, 12, 26-48.

89. Svendsen, E. Storyline and design: How civic stewardship shapes urban design in New York City. In Resilience in Ecology and Urban Design: Linking Theory and Practice for Sustainable Cities; Pickett, S.T.A., Cadenasso, M.L., McGrath, B., Eds.; Springer: New York, NY, USA, 2013; pp. 269-287.

90. Mouffe, C. Art and Democracy: Art as an Agnostic Intervention in Public Space. Open Art Public Issue 2008, 14, 6-15.

91. Hardt, M.; Negri, A. Commonwealth; Harvard University Press: Cambridge, UK, 2009.

92. Miss, M. Remixing messages: A call for collaboration between artists and scientists. In Resilience in Ecology and Urban Design: Linking Theory and Practice for Sustainable Cities; Pickett, S.T.A., Cadenasso, M.L., McGrath, B., Eds.; Springer: New York, NY, USA, 2013.

93. Ellin, N. Integral urbanism: A context for urban design. In Resilience in Ecology and Urban Design: Linking Theory and Practice for Sustainable Cities; Pickett, S.T.A., Cadenasso, M.L., McGrath, B., Eds.; Springer: New York, NY, USA, 2013; pp. 63-78.

94. North, A.; Waldheim, C. Landscape urbanism: A North American perspective. In Resilience in Ecology and Urban Design: Linking Theory and Practice for Sustainable Cities; Pickett, S.T.A., Cadenasso, M.L., McGrath, B., Eds.; Springer: New York, NY, USA, 2013.

95. Felson, A.J.; Pickett, S.T.A. Designed experiments: New approaches to studying urban ecosystems. Front. Ecol. Environ. 2005, 3, 549-556.

96. Hager, G.W.; Belt, K.T.; Stack, W.; Burgess, K.; Grove, J.M.; Caplan, B.; Hardcastle, M.; Shelley, D.; Pickett, S.T.A.; Groffman, P.M. Socioecological revitalization of an urban watershed. Front. Ecol. Environ. 2013, 11, 28-36.

97. Harlem Park, Baltimore, example. Available online: http://sce.parsons.edu/studiocourses/ BaltimoreStudio2010/ (accessed on 12 March 2015).

98. Baltimore Ecosystem Study Urban Design Working Group. Available online: http://beslter.org/ frame4-page_3i_07.html (accessed on 12 March 2015).

99. Felson, A.J.; Oldfield, E.E.; Bradford, M.A. Involving ecologists in shaping large-scale green infrastructure projects. BioScience 2013, 63, 882-890.

100. McGrath, B.; Marshall, V.; Cadenasso, M.L.; Grove, J.M.; Pickett, S.T.A.; Plunz, R.; Towers, J. Designing Patch Dynamics; Columbia University: New York, NY, USA, 2007.

(C) 2015 by the authors; licensee MDPI, Basel, Switzerland. This article is an open access article distributed under the terms and conditions of the Creative Commons Attribution license (http://creativecommons.org/licenses/by/4.0/). 